\title{
Reparation of peripheral nerves with fibrin glue prepared from snake venom. Preliminary results
}

\author{
Universidade do Estado de São Paulo (UNESP) - São Paulo, Brazil
}

\begin{abstract}
A new fibrin glue obtained from snake venom is presented, with possible utilization in various fields of medicine. The preparation procedures and tests in the reparation of peripheral nerves are described. The preliminary results were similar to the conventional fibrin glue procedure.
\end{abstract}

UNITERMS: Fibrin glue. Snake venom. Peripheral nerves. Rats.

$\mathrm{A}$ trombim-like fraction was isolated from crude Crotalus snake venom through molecular exclusion and affinity chromatography (1). The active fractions were pooled and concentrated by dialysis $(1,2,8)$. The pool was analyzed for protein concentration (6) and characterized by sodium-dodecil-sulfate polyacrilamide gel electrophoresis and immunoblotting (SDS-PAGE). The fibronogen source was the wet cryoprecipitate obtained from fresh human plasma through

\section{Address for correspondence:}

Fausto Viterbo

Rua José Del Farra 592

Botucatu - SP - Brasil - CEP 18603-790 cold precipitation, containing an average of $120 \mathrm{mg} / 100$ $\mathrm{ml}$ of fibrinogen (8).

The fibrin glue was obtained from the solution 1 (cryoprecipitate containing fibrinogen) (9) and the solution 2 (trombin-like snake venom fraction). The area to be glued was prepared, receiving Solution 1 as a first step, followed by application of equal volume of Solution 2 on top of it. After application, the rite was tightly in place for three minutes, so as to obtain firm adhesiveness $(3,4,7,8)$. This procedure was tested for the reparation of sciatic nerves in Wistar rats, yielding results similar to those reported by other with conventional fibrin glue $(5,7)$. The efficacy of the Snake Venom Glue can be evaluated through figures 1-3: the normal aspect of sciatic nerve (Fig. 1); the distal ending, after reparation by the Snake Venom fibrin Glue (Fig. 2); the number of nerve fibers is lower than in the proximal ending. When the distal ending was not repaired (Fig. 3), extensive fibrosis and absence of nerve fibers was seen. Comparing figures 2 and 3 , we can conclud that 


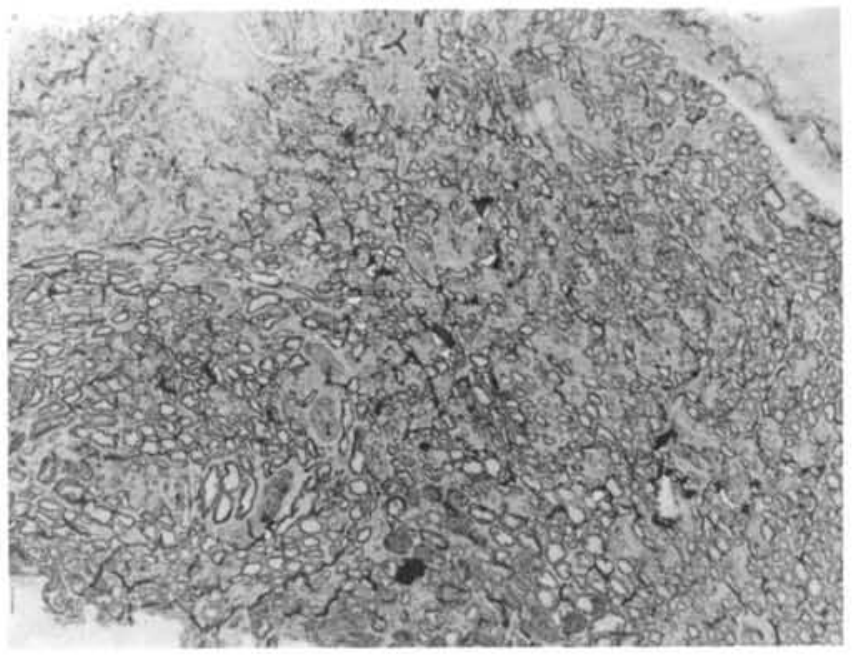

Figure 1. Transverse cut of rat sciatic nerve, proximal stump, with normal characteristics (16x)

the fibrin glue allowed adequate adherence and nerve regeneration.

\section{ACKNOWLEDGMENTS}

We thank Prof. Dr. Romeu C. Guimarães very much for the final revision of the text, Ana Maria Meluso by her precious collaboration in animal management and $\mathrm{Mr}$. Silvio Garcia Manoel for photographic documentation.

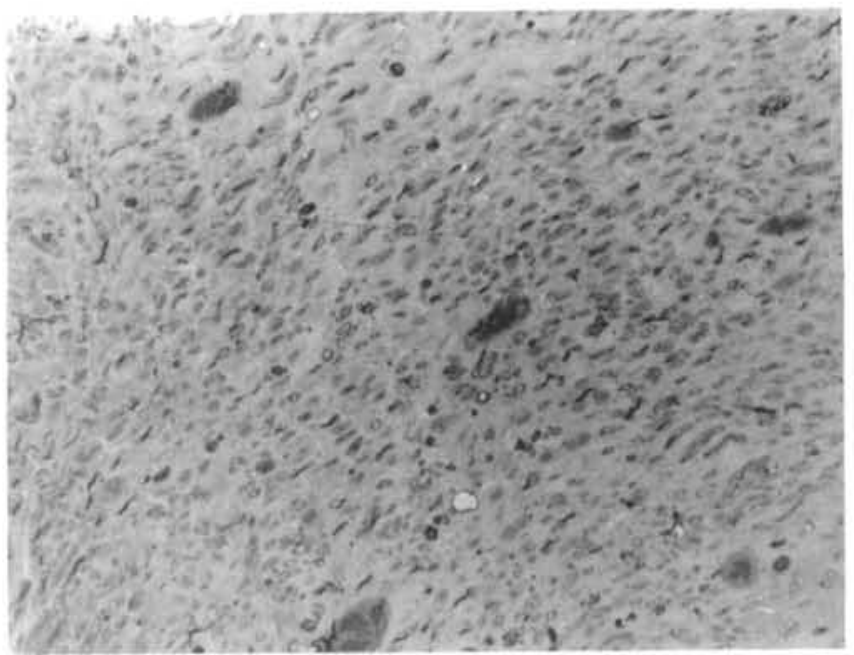

Figure 2. Transverse cut of rat sciatic nerve, right side. Distal stump, repaired by the fibrin glue derived from the snake venom (16x).

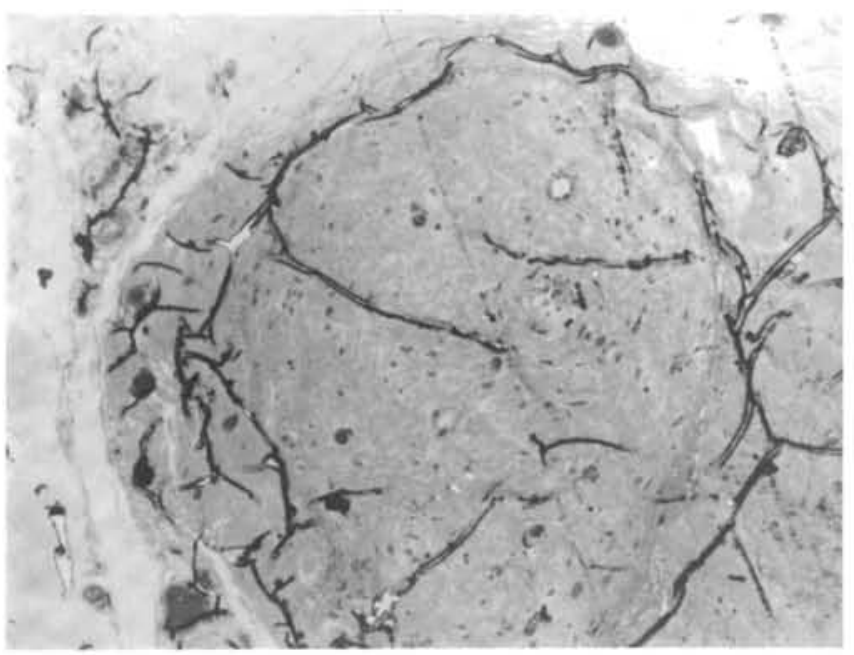

Figure 3. Transverse cut of rat sciatic nerve, left side, not repaired, distal stump (16x).

\section{Resumo}

Objetivo: Os autores apresentam um novo produto denominado cola de fibrina derivada de veneno de cobra, com possivel utilizaçāo em várias áreas da medicina. Material e Métodos: Descrevem seu processo de preparaçăo e a reparação em nervo periférico. Resultados: Os resultados preliminares obtidos foram semelhantes aos da cola de fibrina convencional. 


\section{REFERENCES}

1. ALEXANDER, G.; GOOTHUSEN, J.; ZEPEDA, H. \& SCHWARTZMAN, R.J. - Gyroxin, a toxin from the venom of Crotalus durissus terrificus, is a trombin-like enzyme. Toxicon 26(10):953, 1988.

2. BARRABIN, H.; MARTIARENA, J.L.; VIDAL, J.C. \& BARRIO, A. - Isolation and characterization of gyroxin from Crotalus durissus terrificus venom. In: ROSENBERG, P. Toxins: Animals, plant and microbial. New York. Pergamon Press, 1978, p. 133.

3. BAKER, J.W.; SPOTNITZ, W.D.; MATTHEW, T.L. \& NOLAN. S.P. - Successful use of fibrin glue during 2 years of surgery at a University Medical Center. Am Surg 55(3):166, 1989.

4. BORST, H.G.; HAUERICH, A.; WALTERBUSH, G.; MAATZ, W. \& MESSNER. B. - Fibrin adhesive: An important hemostatic adjunct in cardiovascular operations: J. Thorac. Cardiovasc. Surg. 84:548, 1982.
5. KLETHER. G. - Comparative evaluation of conventionally sutured and clot-sutured microsurgical anastomosis. In: SCHEIEDER, P. Microsurgery for stroke. New York, Springer-Verlag, (Ch, 19).

6. LOWEY, O. H.; ROSEBROUGH, N.J.; FARR, A.L. \& RANDALI, R.J. - Protein measurement with the folin phenol reagent. I Biol Chem 193:265-275, 1951.

7. LUPINETTI, F.M.; STONY, W.S.; ALFORD Jr, W.C.; BUJRMS, G.R.; CLASSFORD, Jr, D.M.; PETRACECK, M.R. \& THOMAS, C.S. - Cryoprecipitate-topical Trombin Glue. Initial experience in patients undergoing cardiac operations. J. Thorac Cardio-vasc. Surg. 90:502, 1985.

8. MARLAND, F.S. \& PIRKLE, H. - Biological activities and biochemical properties of thrombin-like enzymes from snake venoms. In: LUNDBLAD, R.L; ENTON, J.W; MANM, K.G; Chem and Biol of Trombin. Ann Arbor Science. Ann Arbor, Michigan, 1977, p 71.

9. WALKER, R.H. - Blood and blood components: preparation, storage and shipment. In: Technical Manual of American Association of blood banks (A.A.B.B.), Ch 3, 10 ed., 1990, p. 47. 